\title{
Dr. Albert Hertzog se bemoeienis met die Mynwerkersunie
}

\author{
WESSEL VISSER*
}

\begin{abstract}
Opsomming: In 1975 het Dan O’Meara die boek van L Naudé, $\operatorname{Dr}$ A. Hertzog, die Nasionale Party en die Mynwerkers, vir die South African Labour Bulletin geresenseer. Daarin bespreek O'Meara die stryd en motiewe van die Afrikaner politieke en kulturele elite om 'n Afrikaner-nasionalisties-georiënteerde leierskap teen 1948 in beheer van die Mynwerkersunie (MWU) te stel. Resente navorsing, gebaseer op ' $n$ in diepte studie van die Hertzog-Versameling by die Instituut vir Eietydse Geskiedenis in Bloemfontein, asook ander dokumente, het Hertzog se verdere intieme betrokkenheid by hierdie vakbond in die post1948 periode aan die lig gebring. Aantygings van korrupsie teen die MWU se hoofsekretaris, Daan Ellis, het tot smeerveldtogte, mosies van wantroue en kommissies van ondersoek na korrupsieklagtes en wanbestuur aanleiding gegee. Dit het 'n onverkwiklike magstryd tussen PJ Visser, die president van die MWU, en Ellis tot gevolg gehad. Hertzog was ten nouste daarby betrokke. Hertzog en lede van die Afrikaner politieke- en kulturele-elite was besorg dat die twis en onmin binne die vakbond uiteindelik die beeld van die MWU by blanke mynwerkers, en Afrikanermynwerkers in die besonder, kon benadeel wat op sý beurt weer polities ' $n$ negatiewe gevolge vir die NP by die stembus kon inhou. Daarom sou Hertzog probeer om met die bestuur van die vakbond in te meng en selfs lede van die Afrikaner Broederbond het gepoog om die magstryd binne die MWU te ontlont. Hierdie artikel poog om 'n aspek van die politieke lewe van dr. Albert Hertzog te belig, aangesien daar nog geen deurtastende wetenskaplike historiese ondersoek na die politieke lewe van hierdie omstrede figuur in die Suid-Afrikaanse geskiedenis gedoen is nie.
\end{abstract}

Trefwoorde: Albert Hertzog, Mywerkersunie, vakbondwese in SuidAfrika, Nasionale Party, Afrikanernasionalisme, arbeid

\section{Inleiding}

In 1975 het die revisionistiese historikus, Dan O'Meara, die boek van Louis Naudé, Dr. A. Hertzog, die Nasionale Party en die Mynwerkers ${ }^{1}$ vir die South African Labour Bulletin geresenseer. In breë trekke handel die boek oor Hertzog se betrokkenheid by die intense stryd om die

* Dr Wessel Visser is verbonde aan die Departement Geskiedenis aan die Universiteit van Stellenbosch. Die artikel is gebaseer op 'n navorsingsprojek deur die skrywer oor die geskiedenis van die Mynwerkersunie wat eersdaags in boekvorm verskyn.

1 Pretoria: Nasionale Raad van Trustees, 1969. "Louis Naudé" is die pseudoniem vir Beaumont Schoeman, wat aanvanklik die assistent-redakteur van die konserwatiewe, Nasionaalgesinde Perskor-koerant Hoofstad was en wat later die redakteur van Die Afrikaner, die lyfblad van dr. Hertzog se Herstigte Nasionale Party, geword het. 
politieke beheer van die Mynwerkersunie (MWU) gedurende die dertigeren veertigerjare van die twintigste eeu. Dit speel af teen die agtergrond van die opwelling van Afrikanernasionalisme, korrupsie en wanadministrasie in die vakbondbestuur, pogings van die Afrikaner-elite om die Afrikanermynwerkers polities te betrek ten einde ' $n$ verkiesingsoorwinning vir die Nasionale Party (NP) in 1948 te realiseer en om uiteindelik ook ' $n$ pro-NP-beheer van die MWU te bewerkstellig. Volgens O'Meara is die boek die verhaal van ' $\mathrm{n}$ blatante poging deur Afrikanerorganisasies soos die NP, die Afrikaner Broederbond (AB) en Hertzog se Nasionale Raad van Trustees (NRT) om die Afrikanerwerkers van hulle werkersklassolidariteit met werkersorganisasies soos die Suid-Afrikaanse Arbeidersparty en die South African Trades and Labour Council te "speen" en hulle dan tot die ekonomiese voordeel van Afrikanerelite-belange in " $\mathrm{n}$ monolitiese Afrikanernasionalisme te mobiliseer. O'Meara staan krities teenoor die feit dat die boek baie subjektief en eensydig geskryf is as 'n rasionaal vir Hertzog se bemoeienis by die MWU ter wille van die toendertydse Afrikanerpolitiek. ${ }^{2}$

Ook Linda de Kock, in haar die MA-verhandeling, "Die Stryd van die Afrikaner in die Suid-Afrikaanse Mynwerkersunie aan die Witwatersrand, 1936-1948"3 ondersoek onder andere Hertzog se aandeel aan die MWU se betrokkenheid by Afrikanernasionalisme in die genoemde periode.

Hierdie werke skep die indruk dat Hertzog se bemoeienis met die vakbond eindig met 'n NP-gesinde bewindsoorname van die MWU se uitvoerende bestuur teen die einde van 1948. Nuwe navorsing vanuit die JAM Hertzogversameling by die Instituut vir Eietydse Geskiedenis (INEG) aan die Universiteit van die Vrystaat dui egter daarop dat Hertzog tot ongeveer 1951 aktief by die vakbond betrokke sou bly en ook daarna sporadies met die vakbondbestuur en die mynwerkers kontak behou het. Hertzog se aktiewe betrokkenheid by die MWU tussen 1948 en 1950, die redes vir sy amptelike onttrekking daaraan, asook sy verdere bemoeienis met die vakbond word in hierdie artikel bespreek.

\section{Albert Hertzog en die Hoek-kommissie van Ondersoek}

Reeds met die bewindsaanvaarding van die nuwe NP-gesinde MWUuitvoerende bestuur het Hertzog, wat nooit self ' $n$ mynwerker was nie, ' $n$ besondere prominente leiersposisie in die strukture van die vakbond beklee. So het hy in 1949 die voorsitter van Die Werkerspers Uitgewers Maatskappy (Edms.) Bpk. geword - die nuwe maatskappy wat gestig is om onder andere Die Mynwerker, die lyfblad van die MWU, uit te

2 Dan O'Meara: “White Trade Unionism, Political Power and Afrikaner Nationalism” (South African Labour Bulletin, 1/10, 1975, pp. 31-51).

3 RAU, 1991. 
gee. $^{4}$ In dieselfde jaar het die vakbond se eie groeplewensskema en lewensversekeringsmaatskappy, Die Monument Assuransie Korporasie, Beperk, tot stand gebring. Hertzog was ook 'n direksielid daarvan.

Kort nadat die nuwe uitvoerende bestuur die beheer van die MWU oorgeneem het, was daar, volgens koerantberigte, sprake dat 'n nuwe werkersparty, die sogenaamde "Nasionale Werkersparty", met die oog op "doelbewuste politieke aksie in belang van die werkers" in die plek van die kwynende Suid-Afrikaanse Arbeidersparty (SAAP) gestig sou word. ${ }^{6}$ In wat as 'n vernuftige stukkie politieke voetwerk beskou kan word, het die Nasionaalgesinde MWU-bestuur vir Albert Hertzog, die nuwe NP-LV vir Ermelo, as gasspreker genooi om die 1949-jaarvergadering van die vakbond se algemene raad toe te spreek. Alreeds in Januarie daardie jaar is sy nooienstoespraak in die parlement, waarin hy die hervormingsgesinde mynwerkers se stryd om van die ou korrupte Verenigde Party en SAAPgesteunde vakbondbestuur ontslae te raak uiteengesit het, volledig in Die Mynwerker gepubliseer. Tydens sy toespraak voor die MWU-algemene raad het Hertzog, onder andere, voorgestel dat Suid-Afrika se minerale rykdom tot voordeel van sy (blanke) werkers ontgin moes word en dat die goud- en steenkoolmyne tot voordeel van die staat genasionaliseer behoort te word. ${ }^{7}$

Alhoewel Hertzog se nasionaliseringsvoorstel ' $n$ verleentheid vir die NPregering was en dit deur dr. D.F. Malan, die Eerste Minister, en Eric Louw, die Minister van Mynwese, gerepudieer is dat sy standpunt nie die amptelike partybeleid verteenwoordig het nie, ${ }^{8}$ het dit die gewenste uitwerking gehad. Nie net is enige sprake van die stigting van ' $n$ nuwe politieke werkersparty die nek ingeslaan nie, maar die algemene raad, wat Hertzog as 'n kampvegter vir die saak van die mynwerker beskou het, het hom 'n ere-lid van die MWU gemaak. Voorts het die algemene raad "n parlementêre groep, of sogenaamde "waaksaamheidskomitee" van Nasionale LV's, waarvan Hertzog eweneens 'n lid was, in die lewe geroep "om met die Hoofbestuur van die Nasionale Party in verbinding te bly ... vir die bevordering van die mynwerkers se belange". ${ }^{9}$

4 Ivan Walker and Ben Weinbren: 2000 Casualties. A History of the Trade Unions and the Labour Movement in the Union of South Africa. Johannesburg: SATUC, 1961, p. 221; E.S. Sachs: The Choice Before South Africa. London: Turnstile Press, 1952, p.186; Alex Hepple: Trade Unions in Travail. Johannesburg: Prompt Printing, 1953 [?], pp. 42-43.

5 "The Monument Insurance Corpn. Ltd" (Die Mynwerker, 29.11.1949, p. 9).

6 "Hoofartikel" (Die Mynwerker, 22.4.1949, p. 7); "Mineworkers' Union may form new political party (Rand Daily Mail, 25.4.1949); "Mineworkers and Nats." (The Cape Times, 21.6.1949); "Mynwerkers net ontevrede met die regering" (Die Vaderland, 26.4.1949).

7 “...Die Volk wat sy werkers misken moet onder gaan..." (Die Mynwerker, 28.1.1949, pp. 7,10); "Nasionalisering van Myne" (Die Mynwerker, 22.4.1949, p. 9).

8 Walker and Weinbren: 2000 Casualties, pp.220-221; Hepple: Trade Unions in Travail, p. 40; Sachs: The Choice Before South Africa, p. 92.

9 "Nuwe Groep in Volksraad" (Die Mynwerker, 22.3.1949, p. 1); "Nasionalisering van Myne", "M.W.U. en Politiek" en "Verslag aan Algemene Raad" (Die Mynwerker, 6.5.1949, pp.7-8,10); "Parlementêre Groep vir die Mynwerkers" (Die Transvaler, 26.4.1949). 
Hoewel die bewindsoorname van die nuwe bestuur op politieke terrein ' $n$ tydperk van kalmte en stabiliteit in die vakbond sou inlui, het spoke van korrupsie, onreëlmatighede en twis tussen persoonlikhede, egter spoedig weer in MWU-geledere begin opdoem. 'n Nuwe uitgerekte twis en onverkwiklikheid het tussen Jan Gleisner, die redakteur van Die Mynwerker, Paul Visser, die MWU-president en Albert Hertzog aan die een kant, en Daan Ellis, die nuwe NP-gesinde hoofsekretaris en sy uitvoerende bestuur aan die ander kant, uitgebreek. Die oorsprong daarvan was beweringe van korrupsie en wanadministrasie teen Ellis, 'n feit wat verswyg word in Naudé se werk oor die MWU. ${ }^{10}$ Die goeie verhouding tussen Hertzog en Visser aan die een kant, en Ellis aan die ander kant gedurende die twaalf jaar lange "Hervormerstryd" om die beheer van die MWU, sou om 'n aantal redes versuur. In die persoonlike dagboeke van Hertzog aangaande sy verbintenis met die mynwerkers ontvou 'n verhaal van die geleidelike verbrokkeling van die verhouding tussen hom en Ellis wat aan verskeie faktore toe te skryf was. Onderliggend daaraan was die konteks waarbinne Hertzog sy posisie in en verhouding met die MWU beskou het. In die eerste plek het beide Hertzog en Ellis oor sterk persoonlikhede beskik wat maklik tot konfrontasie kon lei. ${ }^{11}$

' $n$ Sentrale faktor in die bepaling van die verhouding tussen Hertzog en Ellis was die feit dat eersgenoemde homself as die intellektuele en politieke voog en mentor van die (minder geletterde) Afrikanermynwerker beskou het. Baie van die mynwerkers het dit inderdaad self so ingesien. Die Afrikaner intellektuele en kulturele elite, soos verteenwoordig deur Hertzog en die NRT, het spesifieke doelwitte aangaande die Afrikanerwerker nagestreef. Wat die mynwerkers betref, was dit Hertzog se strewe om hulle "'n magtige faktor [te maak] wat leiding sal gee en wat 'n bolwerk sal vorm teen die groot kapitalisme wat besig is om ons volk te oorrompel". Ten einde te verseker dat die "Nasionale Afrikanerdom" vir "n aansienlike tyd aan bewind sou bly, het die rol van Afrikanerwerkers en die vakbonde vir Hertzog van kardinale belang geraak. Hy was van mening dat tensy "hierdie groot massa van werkers grootliks vir ons saak gewen word...die toekoms vir die Afrikanervolk...vir goed verlore" was. Volgens hom het die MWU, wat na "n verbete stryd uiteindelik vir die Afrikanersaak "gewen" is en wat sonder sy toedoen nie moontlik sou wees nie, 'n morele plig gehad om veral " $n$ materiële bydrae te lewer ten einde ander vakbonde, soos dié vir klere- en bouwerkers, te help "red" van die "verderflike" invloed van kommunisme en die daarmee gepaardgaande rasse-integrasie. Sodoende

10 O'Meara: "White Trade Unionism", p. 33.

11 Hepple: Trade Unions in Travail, p. 41. Die sogenaamde "Hervormerstryd" verwys na die twaalfjaarlange stryd wat vanaf 1936 tot 1948 in die MWU geduur het om van die korrupte pro-Verenigde Party en pro-SAAP vakbondbesture van Charles Harris en Bertie Brodrick ontslae te raak. In die proses is as teenvoeter eers die Afrikanerbond van Mynwerkers (ABM) en in 1938 die Hervormingsorganisasie (kortweg die Hervormers genoem) onder leiding van NRT gestig. Sien in die verband Naudé: Dr. A. Hertzog en De Kock: "Die Stryd van die Afrikaner". 
sou daardie vakbonde ook vir die Afrikanersaak en die NP "oorwin" kon word.

Aangesien die hoofsekretaris so 'n magtige en onaantasbare posisie in die MWU beklee het, het Hertzog om bogenoemde redes gevoel dat die NRT “'n mate van beheer" oor die vakbond (en ook oor ander vakbonde) moes verkry aangesien sy bestaande "houvas" daaroor "kwesbaar" en "broos" was. Vir Hertzog was sodanige strategie "nooit "n sogenaamde magstrewe nie", maar "'n noodsaaklikheid". "n Hoofsekretaris (soos Ellis) het die vakbond se organisatoriese struktuur beheer en kon betaalde amptenare aanstel of ontslaan sodat hulle "feitlik instrumente in sy hand" was. Deurdat hulle bang sou wees om die hoofsekretaris teë te gaan en dus maklik deur hom beïnvloed is om slegs sy bevele uit te voer, het hy so ook beheer oor die uitvoerende bestuur kon uitoefen om volgens sy wil op te tree. Op sý beurt kon dit weer tot "magsmisbruik, finansiële wanbestuur en korrupsie" lei.

"n "Onafhanklike" hoofsekretaris was derhalwe vir Hertzog se strategiese visie met die MWU 'n probleem. Daarom was dit vir hom belangrik om die mag van die hoofsekretaris "aan perke te lê" en sy eie magsinvloed in die vakbondbestuur te hê "om "n sekretaris te kan ontslaan of te kan skors" indien nodig. Hertzog het, na aanleiding van die ondervinding met die korrupte Harris-Brodrick-besture gedurende die Hervormerstryd, die mynwerkers klaarblyklik nie vertrou om hulleself te bestuur nie. Dit blyk dat hy op verskeie wyses sy beheerstrategie oor die MWU-bestuur wou vestig deur middel van "n "klein adviserende komitee", bestaande uit NRT-lede "wat feitlik alle besluite van belang sou neem", en "n "besigheidsbestuurder" wat Ellis moes "bystaan" en "leiding" aan hom moes verskaf, maar wat as die eintlike mag agter die troon moes optree. As "besigheidsbestuurder" vir die MWU het Hertzog Schalk Botha, "n lid van die NRT, in die oog gehad. Daar hy alreeds met die oorwinning van die Hervormingsgesindes in 1948 in die bestuur van die MWU as koningmaker opgetree het deur Daan Ellis tot hoofsekretaris verkies te kry, sou Hertzog dit ook oorweeg om Botha as NRT-lid en "Hertzogman" as alternatief op die vakbondbestuur aangestel te kry. Sodoende sou Botha namens Hertzog "beheer" oor Ellis kon uitoefen toe die gerugte van onreëlmatighede in laasgenoemde se administrasie al hoe sterker begin raak het. ${ }^{12}$

12 Instituut vir Eietydse Geskiedenis (hierna INEG) PV 451, JAM Hertzog-Versameling, Lêer nr. 4/1/179: Dagboek, Februarie 1950, p.2693, Mei 1950, p.2807, Julie 1950, p.2901, Augustus 1950, p.2992; Ibid., Lêer nr. 4/1/180: Dagboek, Augustus 1950, pp. 3028-3030, 3036-3040, September 1950, pp. 3058, 3079, 3082-3083, Oktober 1950, p. 3107, Desember 1950, pp. 3204-3205; Ibid., Lêer nr. 4/1/182: Dagboek, Maart 1951, pp. 3677-3678, Mei 1951, p.3751, Oktober 1951, pp. 3957-3959, 3961, 4061, 40664067; Ibid., Lêer nr. 4/1/184, Januarie-Desember 1952, pp. 4367-4370, 4648; Ibid., Lêer nr. 4/1/209: Dagboek, Julie 1948, p. 490; Ibid., Lêer nr. 4/1/210: Dagboek, April 1949, p.571, November 1949, p. 705; Transvaalse Argiefbewaarplek (hierna TAB) A 1731 SJ Botha-Versameling, Vol.8: Getuienis, Vrae gestel aan mnr. Gleisner, 4.8.1950, pp. 8-9. 
Ellis, daarenteen, wou al hoe meer onafhanklik in die MWU optree sonder inmenging deur politieke persoonlikhede soos Hertzog, terwyl Hertzog verwag het dat Ellis sy "leiding" moes aanvaar en dit sou op sigself toenemend op ' $\mathrm{n}$ botsing van standpunte neerkom. In sy dagboeke het Hertzog verklaar dat "nadat die Unie [deur hervormingsgesindes] ingeneem was, was Ellis nie meer ons [NRT] amptenaar nie" en dat "ons...nie meer dieselfde mag oor Ellis gehad [het] nie". Na sy bewindsaanvaarding het Ellis byvoorbeeld nie meer die NRT uit eie inisiatief oor belangrike vakbondaangeleenthede geraadpleeg nie. ${ }^{13}$ Ellis was klaarblyklik ook nie gediend met die baie publisiteit wat Hertzog in verband met die MWU geniet het nie daar dit die indruk kon skep dat hy in terme van vakbondaangeleenthede deur Hertzog in die skadu gestel is. ${ }^{14}$

' $n$ Verdere faktor wat tot ' $n$ versuring in die verhouding tussen Hertzog en Ellis bygedra het, was die toenemende wrywing wat algaande tussen Ellis en Jan Gleisner oor die bestuur van Die Werkerspers en Die Mynwerker opgebou het. Aangesien Die Werkerspers-maatskappy deur Hertzog se inisiatief tot stand gekom het, het Gleisner dit onder sy voogdyskap bestuur. Gevolglik het ook die redaksionele beheer van Die Mynwerker by Gleisner, en nie by Ellis as uitvoerende hoof van die MWU nie, berus. Dit het egter ' $n$ taktiese flater geblyk te wees. Aangesien die vakbond elke maand sy aantal eksemplare van Die Mynwerker by Die Werkerspers-maatskappy gekoop het, het Ellis Gleisner se redaksionele onafhanklikheid oor MWUbeleid probeer kniehalter deur die MWU-rekening maandeliks te laat te betaal of slegs ' $n$ gedeelte daarvan te vereffen. Ten einde vas te stel of enige finansiële verliese ten opsigte van die uitgee van Die Mynwerker bewys kon word, het Ellis op eie houtjie en sonder om vir Gleisner te raadpleeg ouditeure aangestel om Die Werkerspers se state te ouditeer.

Bydraend tot die gespanne verhouding tussen Gleisner en Ellis was die feit dat eersgenoemde deur Hertzog se toedoen as bestuurder van Die Werkerspers en redakteur van Die Mynwerker aangestel is en deur hom as onmisbaar beskou is in die konsolidering van die posisie van die MWU as 'n Nasionaal-georiënteerde vakbond en in die voortgesette stryd om ook die klere- en bouwerkersvakbond te oorwin. Onafhanklik van Ellis en eerder lojaal aan Hertzog, het Gleisner boonop homself as Ellis se intellektuele meerdere beskou. Gleisner se inmenging in MWUadministratiewe aangeleenthede, wat buite sy jurisdiksie geval het, het Ellis mateloos geïrriteer. Daarom het Ellis hom as 'n bedreiging gesien en hom waarskynlik met professionele jaloesie en argwaan bejeën. Ellis het die situasie dus algaande onhoudbaar vir Gleisner gemaak wat ook tot frustrasie by Hertzog gelei het, aangesien die oneffektiewe funksionering

13 (INEG) PV 451, JAM Hertzog-Versameling, Lêer nr. 4/1/180: Dagboek, Desember 1950, pp. 3188-3189; Ibid., Lêer nr. 4/1/182: Dagboek, Mei 1951, pp. 3744,3746; Ibid., Lêer nr. 4/1/184: Dagboek, Januarie-Desember 1952, p. 4370; Ibid., Lêer nr. 4/1/209: Dagboek, Julie 1948, p. 489; Ibid., Lêer nr. 4/1/210, Mei 1949, p. 600, Augustus 1949, pp. 636-637.

14 Ibid., Lêer nr. 4/1/179: Dagboek, Julie 1950, p. 2853. 
van Die Werkerspers ook sý ideaal van die verowering en beheer van die totale blanke vakbondwese in Suid-Afrika verydel het. In hierdie onverkwiklike atmosfeer van wedersydse afkeer het die verhouding tussen Gleisner en Ellis stapsgewys onherstelbaar verbrokkel. ${ }^{15}$

Hertzog beweer ook in sy dagboeke dat dit eintlik Ellis was wat agter die voorgenome poging gesit het om die sogenaamde "Nasionale Werkersparty" te stig. ${ }^{16}$ Teen hierdie agtergrond het Hertzog al hoe meer in Ellis se motiewe, lojaliteit en opregtheid begin twyfel. 'n Verdere faktor wat tot verwydering tussen die twee aanleiding sou gee, was die feit dat Hertzog van mening was dat die MWU, as 'n vakbond wat reeds vir die saak van die Afrikanerwerker "gered" was, 'n finansiële bydrae moes maak waarmee Solly Sachs, die vermaarde algemene sekretaris van die Garment Workers' Union en geswore vyand van die NRT, in die "klerewerkerstryd" beveg kon word. In hierdie verband het Hertzog gedurig druk op Ellis uitgeoefen om 'n ooreengekome bedrag van $£ 10000$ te skenk waarvan 'n gedeelte aangewend sou word om Die Werkerspers in die vakbondstryd teen lasteraksies te dek. Hertzog was aanvanklik onder die indruk dat die MWU hierdie bedrag jaarliks beskikbaar sou stel. Hy was teleurgesteld toe Ellis egter verklaar het dat dit slegs ' $n$ eenmalige skenking sou wees. Voorts beweer Hertzog in sy dagboeke dat Ellis nooit entoesiasties oor hierdie stryd was nie. Teen 1951 het die fondse vir die klere- en bouwerkerstryd opgedroog. Hierdie NRT-offensief moes dus gestaak word, waarvoor Hertzog vir Ellis kwalik geneem het. ${ }^{17}$ Daarby het Ellis onderneem dat die MWU 20000 se aandele in Monument

15 Ibid., Februarie 1950, pp.2694-2698, Maart 1950, pp. 2701-2703, April 1950, pp.27312732, Mei 1950, pp. 2774, 2778-2780, 2787, 2790-2791, 2797, 2808, Junie 1950, pp. 2809-2810, Julie 1950, pp. 2836, 2842-2844, 2853-2854, 2856, 2858, 2860-2862, 2903, 2905, 2907-2908; Ibid., Lêer nr. 4/1/180: Dagboek, Augustus 1950, pp. 29222923, 3033, Desember 1950, pp. 3191, 3193-3195; Ibid., Lêer nr. 4/1/183: Dagboek, Oktober 1951, pp. 4074-4075, 4087-4089; Ibid., Lêer nr. 4/1/208: Dagboek, Oktober 1947, pp. 234-235; Ibid., Lêer nr. 4/1/210, April 1949, pp. 573, 580, 584-585; Julie 1949, pp. 607-609, 636; Augustus 1949, p. 640, Oktober 1949, pp. 696-699, $701-$ 702.

16 Ibid., Lêer nr. 4/1/180: Dagboek, September 1950, p.3067, Desember 1950, 3189; Ibid., Lêer nr. 4/1/183: Dagboek, Oktober 1951, p. 4097; Ibid., Lêer nr. 4/1/184: Dagboek, Januarie-Desember 1952, p. 4370; Ibid., Lêer nr. 4/1/210: Dagboek, April 1949, pp.571-572. Hertzog beweer in sy dagboeke dat hy Ellis beweeg het om van die plan af te sien en dit toe stil gehou het van die NP en die mynwerkers. Geen ander inligting wat hierdie stelling bevestig of weerlê, kon opgespoor word nie.

17 (INEG) PV 451, JAM Hertzog-Versameling, Lêer nr. 4/1/179: Dagboek, Januarie 1950, p.2662, Februarie 1950, pp. 2663-2664, 2692, 2697, Maart 1950, pp. 2704, 2707, April 1950, p. 2739, Mei 1950, pp. 2777-2778, 2780; Ibid., Lêer nr. 4/1/183: Dagboek, Desember 1951, pp. 4771-4173; Ibid., Lêer nr. 4/1/184: Dagboek, Januarie-Desember 1952, pp. 4370-4371; Ibid., Lêer nr. 4/1/209: Dagboek, Julie 1948, p. 490; Ibid., Lêer nr. 4/ 1/210: Dagboek, April 1949, p.568. Sien ook (TAB) A 1731 SJ Botha-Versameling, Vol.6: Aksiekomitee Vakbondnotules 1950-1953, Notule van 'n Samespreking van Belangstellendes, 4.4.1950, p.2 en Notule van 'n Vergadering van die Uitvoerende Komitee van die Aksiekomitee i.v.m. die Vakbondstryd, 17.11.1951, p.2. 
Assuransie sou opneem, maar volgens Hertzog, het eersgenoemde slegs $£ 5000$ as 'n lening aan die maatskappy beskikbaar gestel. ${ }^{18}$

Klaarblyklik was Ellis se sedelike gedrag ook nie altyd ewe onberispelik nie. Dit het vir Hertzog 'n ernstige morele dilemma geskep. Laasgenoemde se dagboeke getuig van vele gerugte en beweringe oor Ellis se voorliefde vir perdewedrenne (wat hom by implikasie in die skuld kon dompel en sodoende makliker vatbaar vir omkopery kon maak) en gevalle van oormatige drankgebruik deur hom word ook genoem. Van 'n nog ernstiger aard was 'n aantal gerugte van sogenaamde "immoraliteit" wat waarskynlik op seksuele teistering van sekere van die damespersoneel in die MWU-hoofkantoor neergekom het. ${ }^{19}$

Die stap wat egter as ' $n$ snelleraksie tot die verbrokkeling van die verhouding tussen Hertzog, Visser en Gleisner enersyds, en Ellis en sommige lede van sy uitvoerende bestuur andersyds, sou lei en uiteindelik op openlike vyandskap tussen die partye sou afstuur, was 'n brief wat Gleisner in Junie 1949 aan Ellis gerig het. Daarin het Gleisner, wat homself as ' $n$ morele en toesighoudende gewete van die MWU beskou het, 'n aantal beskuldigings teen Ellis gerig. Gleisner was onder andere uiters besorg oor die langtermyn beleggingstrategie wat Ellis met die MWU se fondse gevolg het. Ellis het byvoorbeeld groot bedrae geld uitgeleen aan kliënte vir die aankoop van onontwikkelde grond waarvan die waarde spekulatief was. Sou die MWU deur een of ander finansiële krisis getref word, sou dit nie moontlik wees om hierdie bates onmiddellik likied te maak nie wat dit dus 'n uiters riskante belegging gemaak het. Een van hierdie kliënte was glo dr. FJ Kritzinger, 'n omstrede Witwatersrandse eiendomsagent. ${ }^{20}$

In 'n brief aan Albert Hertzog in Desember 1949 het Gleisner ernstiger aantygings gemaak as sou Ellis hom aan omkopery tydens die aankoop van 'n gebou as nuwe hoofkwartier vir die MWU skuldig gemaak het

18 (INEG) PV 451, JAM Hertzog-Versameling, Lêer nr. 4/1/180: Dagboek, November 1950, p.3139.

19 Ibid., Lêer nr. 4/1/179: Dagboek, April 1950, p.2744, Mei 1950, pp.2771-2772,27742775,2778, Julie 1950, pp.2873-2874; Ibid., Lêer nr. 4/1/180: Dagboek, Julie 1950, p.2915, Desember 1950, p.3193; Ibid., Lêer nr. 4/1/182: Dagboek, Maart 1951, p.3684, April 1951, p.3707, Mei 1951, p.3750; Ibid., Lêer nr. 4/1/183: Dagboek, Oktober 1951, p.4202; Ibid., Lêer nr. 4/1/184: Dagboek, Desember 1952, pp.4626-4627; Ibid., Lêer nr. 4/1/186: Dagboek, November 1953, p.5354.

20 (TAB) A 1731 SJ Botha-Versameling, Vol.8: Getuienis, Korrespondensiestukke, J Gleisner - DE Ellis, 25.6.1949; Ibid., Vol.8: Getuienis, Verdere verklaring van mnr. D Ellis, 16.8.1950, Vrae gestel aan mnr. Gleisner, 4.8.1950, pp.3-8,10-12,25,29-33,5165 en Extract from letter to dr. A Hertzog, 13.7.1949; (INEG) PV 451, JAM HertzogVersameling, Lêer nr. 4/1/179: Dagboek, April 1950, pp.2743,2747-2748, Mei 1950, p.2802; Ibid., Lêer nr. 4/1/182: Dagboek, Maart 1951, pp.3687-3688; Ibid., 4/1/210: Dagboek, Mei 1949, pp.595,600,606,717. 
en waardeur dr. Kritzinger 'n buitensporige kommissie verdien het. ${ }^{21}$ Gerugte oor onreëlmatighede in die aankoopproses van 'n eie gebou vir die MWU het ook in mynwerkersgeledere versprei. Vir Hertzog, wat soos reeds genoem gaandeweg al hoe meer aan Ellis se integriteit begin twyfel het, het hierdie gerugte eweneens ' $n$ ernstige morele dilemma en politieke implikasies ingehou. Ten eerste sou dieselfde beskuldigings van korrupsie en wanbesteding van fondse, wat die Hervormers in hulle stryd teen die Verenigde Party- en SAAP-gesinde MWU-besture tydens die HarrisBrodrick-era as aanvalswapen gebruik het, nou teen ' $n$ Nasionaalgesinde MWU-bestuur gebruik kon word. Dit was juis die Nasionaliste wat, toe hulle nog gepoog het om die beheer van die vakbond oor te neem, deugde soos eerlike bestuurspraktyke en skoon administrasie so hoog opgegee het. Hertzog was bevrees dat enige sprake van (hernude) korrupsie in die vakbond "waarskynlik die end van ons [die NRT se] seggenskap" in die MWU sou beteken en dat "daar miskien weer 'n nuwe groep en vyande van die Afrikaner aan bewind van sake [kon] kom". ${ }^{22}$

Ten einde skadebeheer te probeer toepas en die "posisie te red" alvorens die VP-opposisie tot nadeel van die reputasie van die NP daaruit munt sou kon slaan, was dit Hertzog se voorneme om die omkoopbeweringe deur 'n interne kommissie van die MWU te laat ondersoek - 'n strategie wat ook die goedkeuring van Paul Visser, die MWU-president, weggedra het. Om so 'n ondersoekkommissie te loods en bestuur, sou Hertzog egter op die MWU-uitvoerende bestuur gekoöpteer moes word en het hy gevolglik aanhoudend druk op Ellis begin plaas om die vakbond se grondwet dienooreenkomstig te wysig. Alhoewel Ellis by verskeie geleenthede te kenne gegee het dat hy 'n openbare ondersoek na die omkoopbeweringe sou verwelkom, het hy deur vertragingstaktiek dit so ver as moontlik probeer verhinder dat Hertzog op die bestuur beland. Ellis het ook geen

21 (TAB) A 1731 SJ Botha-Versameling, Vol.8: Getuienis, Korrespondensiestukke, J Gleisner - A Hertzog, 10.12.1949; Ibid., Vol.8: Getuienis, Verdere verklaring van mnr. D Ellis, 16.8.1950 en Vrae gestel aan mnr. Gleisner, 4.8.1950, pp.13-26; (INEG) PV 451, JAM Hertzog-Versameling, Lêer nr. 4/1/179: Dagboek, Februarie 1950, p.2694; Ibid., Lêer nr. 4/1/180: Dagboek, Oktober 1950, p.3100, Desember 1950, p.3191; Ibid., Lêer nr. 4/1/210: Dagboek, Desember 1949, p.712.

22 (INEG) PV 451, JAM Hertzog-Versameling, Lêer nr. 4/1/179: Dagboek, Januarie 1950, pp.2655-2657, Februarie 1950, p. 2670, Maart 1950, p.2699, April 1950, p.2743, Mei 1950, p.2780, Julie 1950, pp.2858,2869,2872,2883,2901; Ibid., Lêer nr. 4/1/180: Dagboek, Augustus 1950, pp.3002-3003, 3007-3008, September 1950, p.3045, Desember 1950, p. 3191; Ibid., 4/1/183: Dagboek, Oktober 1951, p.407, Desember 1951, pp. 4171, 4173; Ibid., Lêer nr. 1/266/7/29: J Gleisner, Accusation against DE Ellis, 29.8.1950, p.2; (TAB) A 1731 SJ Botha-Versameling, Vol.8, Getuienis: Verdere verklaring van mnr. Ellis, 16.8.1950 en Vrae gestel aan mnr. Gleisner, 4.8.1950, pp. 24-27. 
poging uit eie inisiatief aangewend om die Departement van Arbeid vir 'n amptelike ondersoek te nader nie. ${ }^{23}$

Alhoewel daar teenstrydige verklarings bestaan oor die omstandighede waaronder dit plaasgevind het, blyk dit dat Hertzog, na volgehoue druk, uiteindelik daarin geslaag het om die MWU-grondwet te laat wysig en deur die Nywerheidsregistrateur goedgekeur te kry sodat hy op die vakbond se uitvoerende bestuur gekoöpteer kon word. Vanuit sy dagboekinskrywings blyk dit dat, ten einde beheer oor die ondersoekproses te kon uitoefen, dit sy strategie was om 'n MWU-komitee, bestaande uit uitvoerende bestuurslede, maar sonder betaalde amptenare soos Ellis en sy organiserende sekretaris ER van Rensburg, aan te stel. Hierdie komitee sou lede vir 'n privaat kommissie van ondersoek selekteer en daardie kommissie sou sy verslag aan die "Hertzog-komitee" lewer wat op sý beurt weer op die mees geskikte optrede sou besluit. Sodoende het Hertzog gepoog om skade aan die MWU se beeld na buite tot die minimum te beperk. Hertzog verklaar dat daar met Ellis gereël is dat 'n uitvoerende bestuursvergadering vir Saterdag 22 Julie 1950 belê sou word waartydens eersgenoemde op die MWU-bestuur gekoöpteer moes word. Hertzog het ook in 'n voorbedagte strategie met Paul Visser ooreengekom om in die omgewing van die vakbond se hoofkwartier te wag totdat sy nominasie aan die bestuursvergadering voorgelê is. Daarna sou Visser hom laat haal. Tydens die besondere vergadering was Ellis egter op besoek aan buitemyne by Sabie, Pelgrimsrus en Gravelotte en het agterna verklaar dat die afstand dit vir hom onmoontlik gemaak het om die byeenkoms betyds by te woon. Hoe dit ook al sy, nadat Hertzog op die bestuur gekoöpteer is, is daar met die klaarblyklike goedkeuring van al die lede teenwoordig voortgegaan om die korrupsiebewerings in Ellis se afwesigheid te bespreek. ${ }^{24}$

Tydens die genoemde bestuursvergadering is 'n sogenaamde "dagbestuur" of "hoofkomitee", bestaande uit die alomteenwoordige dr. Albert Hertzog, Paul Visser, PJ Calitz en HH de Villiers, aangestel wat die ondersoekproses sou inisieer en bestuur. Ten einde te verhoed dat Ellis of Van Rensburg

23 (INEG) PV 451, JAM Hertzog-Versameling, Lêer nr. 4/1/179: Dagboek, Januarie 1950, pp. 2656, 2662, Februarie 1950, pp. 2666-2667, 2696, Maart 1950, p. 2700, Mei 1950, pp. 2793-2794, 2798, 2803-2806, 2808, Julie 1950, pp. 2833, 2849-2852, 2857, 2859-2860, 2868-2869, 2884-2886, 2892-2893, 2895,2900, Augustus 1950, p. 2995; Ibid., Lêer nr. 4/1/180: Dagboek, Augustus 1950, p. 3006, September 1950, pp.30593060,3067, Desember 1950, pp. 3191, 3193, 3196-3197; Ibid., Lêer nr. 4/1/183: Dagboek, Oktober 1951, pp. 4071-4072; (TAB) A 1731 SJ Botha-Versameling, Vol.7, Lêer III: Getuienis, Mynwerkersunie besprekings en ondervragings op 25 Julie 1950; Ibid., Vol.8: Getuienis: Getuienis afgelê deur mnr. DE Ellis, p.22, Verdere verklaring van mnr. D Ellis, 16.8.1950 en Vrae gestel aan mnr. Gleisner, 4.8.1950, p. 24.

24 (INEG) PV 451, JAM Hertzog-Versameling, Lêer nr. 4/1/179: Dagboek, Julie 1950, pp. 2866, 2870, 2873, 2884-2885, 2892-2895, 2898; Ibid., Lêer nr. 4/1/180: Dagboek, Augustus 1950, pp.3007-3008, Oktober 1950, p. 3114; Ibid., Lêer nr. 4/1/183: Dagboek, Oktober 1951, p. 4072; (TAB) A 1731 SJ Botha-Versameling, Vol.8: Getuienis, Verdere verklaring van mnr. D Ellis; Sheila Patterson: The Last Trek. A Study of the Boer People and the Afrikaner Nation. London: Routledge \& Kegan Paul Ltd., 1957, p. 157. 
die werksaamhede van die kommissie aan bande lê of verydel, is onder Hertzog se aanbeveling onafhanklike mag aan die dagbestuur verleen om op eie inisiatief te vergader en te verdaag, terwyl alle vergaderings van die uitvoerende bestuur tydelik opgeskort is. Daar is ook genotuleer dat die dagbestuur aangestel is "om toesig oor die [hoof]sekretaris en sake van die Unie te hou ... terwyl die ondersoek hangende is". Die voorsitter van die kommissie wat aangestel is om die omkoopaantygings binne die MWU te ondersoek, die sogenaamde Hoek-kommissie van Ondersoek, was prof. PW Hoek van die ouditeursfirma Hoek, Wiehahn en Vennote - dieselfde firma wat die vakbond se state geoudit het. Die ander lede van die kommissie was Schalk Botha, 'n Hertzog-vertroueling en NRT-lid, en WF van der Merwe, 'n regsgeleerde van Pretoria. Beide Hoek en Botha was nes Hertzog ook lede van die AB. ${ }^{25}$

Die doel met die aanstelling van die Hoek-kommissie was om die aankoopprosedure van die Transafrika-gebou in Johannesburg as nuwe hoofkantoor van die MWU te ondersoek en die bevindings van die ondersoek aan die uitvoerende komitee van die vakbond te rapporteer. Ondersoek moes ingestel word na gerugte dat die hoofsekretaris van die MWU deur dr. FJ Kritzinger omgekoop is om die spesifieke gebou aan te koop, asook na beweringe dat die Transafrika-gebou teen 'n té hoë prys aangekoop is. ${ }^{26}$ In die uitgawe van Die Mynwerker waarin die aanstelling van die Hoek-kommissie bekend gemaak is, is onder die opskrif "M.W.U. Turns to dr. Hertzog for Leadership" verklaar:

The Executive's decision to elect Dr Hertzog as a member, was prompted by the realization that the presence of the leader at the time when the most far-reaching decisions have to be made, is indispensable...A firm hand and leadership are the demands of the hour. ${ }^{27}$

Waar die verhouding tussen die Hertzog- en Ellis-groeperinge alreeds vooraf gespanne was, het hierdie taktlose en gewraakte uiting deur Gleisner in die MWU-mondstuk, tesame met die besluit om die Hoek-kommissie en die toesighoudende "Hertzog-dagbestuur" in Ellis se afwesigheid aan te stel, ook 'n taktiese flater geblyk te wees en was die vet tussen die twee partye daarna behoorlik in die vuur. Daardeur het Hertzog klaarblyklik sy hand oorspeel. Dit is duidelik dat Ellis dit as 'n poging tot usurpasie van sy mag in die MWU beskou het en verklaar het dat hy "on the war path" was. Hy het nie genoeë geneem "met die polisie wat aangestel was om hom op te pas nie". Van toe af het hy in toenemende mate vir Hertzog,

25 MWU-Argief, Notule van 'n Spesiale Uitvoerende Bestuursvergadering, 22.7.1950, pp.1-2; (INEG) PV 451, JAM Hertzog-Versameling, Lêer nr. 4/1/179: Dagboek, Julie 1950, pp. 2895-2899; Ibid., Lêer nr. 4/1/183: Dagboek, Oktober 1951, pp. 4072-4073, November 1951, p.4117; "E.C. Appoints Commission to Investigate Purchase of M.W.U. Building" (Die Mynwerker, 18.8.1950, p.1).

26 (TAB) A 1731 SJ Botha-Versameling, Vol.7, Lêer I: Verslag van die Kommissie van Ondersoek aangestel deur die Mynwerkersunie by 'n Spesiale Vergadering op 22 Julie 1950 om ondersoek te doen aangaande die aankoop van Transafrika-gebou, pp. 1-2,4.

27 “M.W.U Turns to dr. Hertzog for Leadership" (Die Mynwerker, 18.8.1950, p.1). 
Visser en Gleisner daarvan beskuldig dat hulle met die kommissie van ondersoek 'n sameswering teen hom beplan het. ${ }^{28}$

Ellis se eerste vergeldingstap, om sy gesag in die MWU te herwin, word weerspieël in die agenda vir die MWU-bestuursvergadering van 22 Augustus 1950. Onder andere sou die volgende punte behandel word, naamlik dat: die dagbestuur afgeskaf word; die hoofsekretaris gemagtig word om 'n uitgawe van Die Mynwerker in samewerking met die perskomitee uit te bring waarin die beleid van die uitvoerende bestuur baie duidelik gestel word in verband met die artikel aangaande dr. Hertzog se leierskap wat in die blad se vorige uitgawe verskyn het; die hoofsekretaris die uitgee van Die Mynwerker en die funksies van die dagbestuur oorneem; en die uitvoerende bestuur die direksie van Die Werkerspers versoek om die dienste van Jan Gleisner onmiddellik te beëindig. ${ }^{29}$ Tydens die betrokke bestuursvergadering is die daad by die woord gevoeg. Gleisner is summier as bestuurder van Die Werkerspers en redakteur van Die Mynwerker afgedank en die dagbestuur is ontbind. ${ }^{30}$

Die uitgawe van Die Mynwerkervan 25 Augustus 1950 het in wese dan ook op 'n repudiëring van die uitgawe van 18 Augustus neergekom. Daarin is verklaar dat dr. Albert Hertzog nie verkies is om die leierskap van die MWU oor te neem nie, dat die "gewraakte" berig in die vorige uitgawe van alle waarheid ontbloot was, nie die ware toedrag van sake getrou weerspieël het nie en nie vooraf onder oë van die redaksionele komitee gekom het nie. Die uitvoerende bestuur het die strekking van die berig, dat die MWU hom tot Hertzog gewend het om die leierskap van die vakbond oor te neem, as 'n klap in die gesig van die mynwerkersgemeenskap beskou omdat dit sou impliseer dat in die mynwerkersgeledere niemand was wat daartoe in staat was om die leiding te neem nie. Verder is verklaar dat Hertzog se verkiesing tot die uitvoerende bestuur, in die lig waarin dit in die betrokke berig gestel is, geïnterpreteer sou kon word "as sou die Unie besluit het om toe te tree tot die politieke arena". ${ }^{31}$

In die komende maande het Ellis en die MWU-uitvoerende bestuur, wat hulle geledere agter hom gesluit het, die posisies van Hertzog en

28 (TAB) A 1731 SJ Botha-Versameling, Vol.7, Lêer III: Getuienis, Mynwerkersunie besprekings en ondervragings op 25 Julie 1950; Ibid., Vol.8: Getuienis, Verdere verklaring van mnr. D Ellis, 16.8.1950; MWU-Argief, Notule van Buitengewone Vergadering, 22.8.1950, pp. 1-2; (INEG) PV 451, JAM Hertzog-Versameling, Lêer nr. 4/1/179: Dagboek, Julie 1950, p. 2900; Ibid., Lêer nr. 4/1/180: Dagboek, Julie 1950, p.2915, Augustus 1950, pp. 2923-2924, 2926-2927, 2997-2999, 3006-3007, 3010, 3015, 3018-3019, Oktober 1950, pp. 3100-3101, November 1950, p.3151, Desember 1950 , p. 3197.

29 MWU-Argief, Agenda vir 'n Buitengewone Bestuursvergadering, 22.8.1950; "Belangrike Besluite van die Uitvoerende Bestuur" (Die Mynwerker, 1.9.1950, p. 1).

30 MWU-Argief, Notule van Buitengewone Vergadering, 22.8.1950, p. 2; "Daar word tans ondersoek ingestel" (Die Mynwerker, 25.8.1950, p. 1); "Werkerspers se Bestuurder kry Ontslag" (Die Mynwerker, 1.9.1950, p. 1).

31 "Dr. Hertzog se Posisie in U.B" en "Berig in Vorige Uitgawe Mag Wanindruk Skep meen Uitvoerende Bestuur!” (Die Mynwerker, 25.8.1950, p. 1). 
Visser op die bestuur stelselmatig onverdraagsaam begin maak. Die taktiek van sekere lede van die uitvoerende bestuur was om tydens bestuursvergaderings 'n mosie van wantroue in Visser te stel en sodoende te eis dat hy as MWU-president bedank. Hy is deur middel van 'n wysiging van die MWU-grondwet stelselmatig uitgeskuif en oningelig gehou van alle belangrike MWU-komitees en onderhandelings wat die vakbond aangegaan het. 'n Mosie van wantroue is aanvanklik ook in Hertzog se posisie op die uitvoerende bestuur gestel, maar dit is weer teruggetrek. Daarby het verskeie berigte in die pers verskyn oor mosies van wantroue in Hertzog en Visser wat vanuit distriksbesture van die MWU op sommige myne gestel is. Ellis het ook beweer dat hy op aandrang van Hertzog vir dr. Malan moes oorreed om Hertzog Minister van Arbeid te maak, dat Hertzog ongewild en "uitgebak" in NP-kringe was, dat hy homself wou red deur 'n magsoorname in die vakbonde te verkry om sy politieke doelwitte te bereik, en dat Ellis namens Hertzog die Witwatersrandse afdelingsbestuur van die NP moes "rysmier" deur MWUskagverteenwoordigers daarop aangestel te kry sodat Hertzog beheer van die party op die Rand kon oorneem. Hertzog wou glo beheer oor die MWU kry sodat hy "druk op die mynwerkers kon uitoefen". ${ }^{32}$

Hertzog se vroeë profetiese waarskuwing, dat die intimidasie van Gleisner met sy onstuimige persoonlikheid deur Ellis daartoe sou lei dat hy "gaan terugslaan", "met modder gaan gooi" en "gaan beswadder waar hy kan" sodat die skade "geweldig" gaan wees, ${ }^{33}$ is inderdaad bewaarheid. Gleisner het geensins sy afdanking as bestuurder van Die Werkerspers en redakteur van Die Mynwerker gedweë aanvaar nie en het 'n eis van £1200 teen die Werkerspers en $£ 10000$ teen die MWU as skadevergoeding vir die voortydige beëindiging van sy kontrak en vir kwaadwillige naamskending ingestel. ${ }^{34}$ Aangesien hy bang was dat die Hoek-kommissie van Ondersoek

32 Sien bv. MWU-Argief, Notules van die Maandelikse Vergadering van die Uitvoerende Bestuur, 30.8.1950 tot 30.7.1951; (INEG) PV 451, JAM Hertzog-Versameling, Lêer nr. 4/1/179: Dagboek, Julie 1950, p. 2906; Ibid., Lêer nr. 4/1/180: Dagboek, Augustus 1950, pp. 2977-2979, 2982, 2996-2997, 3000, 3003-3005, 3009, 3027, 3036, September 1950, pp.3058-3059,3078,3082, Oktober 1950, pp. 3101, 3116, November 1950, pp. 3150-3152, Desember 1950, pp. 3198-3202; Ibid., Lêer nr. 4/1/182: Dagboek, Mei 1951, pp. 3746-3748, 3750, Oktober 1951, pp. 4054-4055, 4057-4060, 4074, 40764077; Ibid., Lêer nr. 4/ 1/183: Dagboek, Oktober 1951, p. 4073, 4085-4086; Patterson: The Last Trek, p. 157; "O.F.S. Miners say Hertzog Election will split ranks" (Rand Daily Mail, 24.8.1950); "Ellis asked Malan to make A. Hertzog Minister of Mines (Rand Daily Mail, 19.3.1953); "Free State Miners Hold Meeting of Protest" (The Star, 9.8.1950); "Information withheld on Union President" (The Argus, 27.4.1951); "Visser's Evidence kept him in Witness Box for three Days" (Die Mynwerker, 20.3.1953, p. 3).

33 (INEG) PV 451, JAM Hertzog-Versameling, Lêer nr. 4/1/180: Dagboek, Augustus 1950, p. 2927.

34 Sentrale Argief Bewaarplek (hierna SAB), Archives of the Supreme Court of South Africa, Witwatersrand Local Division, file no. 974/56, Illiquid Case: Jan Gleisner versus Mineworkers' Union, 1952-1953; “Mnr. J. Gleisner stel eis in teen Werkerspers" (Die Mynwerker, 15.9.1950, p. 5). Teen 1954 het die MWU-uitvoerende bestuur besluit om ingevolge 'n skikkingseis $£ 750$ aan Gleisner te betaal. Sien MWU-Argief, Notule van die Uitvoerende Bestuursrvergadering, 20.5.1954, p. 8. 
dalk nie vir Ellis aan korrupsie sou skuldig bevind nie, het Gleisner die kommissielede per brief versoek om hulle ondersoek te staak, onder andere omdat hulle as private ondersoekkommissie geen geregtelike status gehad het nie. ${ }^{35}$

Toe die Hoek-kommissie nie aan Gleisner se versoek om hulle ondersoek te staak gehoor gegee het nie, het hy hulle bevindinge vooruitgeloop deur 'n pamflet op die Rand te versprei. Daarin het hy die hele proses van die aankoop van 'n nuwe gebou vir die MWU, in wat hy as 'n korrupsieskandaal en "leuens" deur Ellis beskou het, uiteengesit. Ten einde 'n hofsaak te vermy wat die bevindinge van die Hoek-kommissie voortydig tot skade van die MWU vooruit sou loop, het Hoek, Hertzog en Ellis egter besluit om nie met regstappe daarop te reageer nie. ${ }^{36}$

Maar ook Albert Hertzog se posisie op die MWU-uitvoerende bestuur het weens sy verslegtende verhouding met Ellis onuithoudbaar geword. Eers het Faas de Wet, die MWU-welvaartsbeampte en lojale ondersteuner van Hertzog sedert die stryddae in die ABM en die Hervormingsorganisasie, hom versoek om dit ernstig te oorweeg om uit die bestuur te bedank. Verder blyk dit dat die Uitvoerende Raad van die AB ook ongemaklik daarmee was dat Hertzog as politikus hom met die bestuur van die MWU bemoei het. Waar die hervormingsgesinde Afrikaners voor die Ellis-bestuur juis partypolitieke inmenging in die MWU beveg het, het dit met Hertzog se intieme betrokkenheid daarby gelyk of hulle dit nou voorgestaan het. Daarom was sommige lede van die Uitvoerende Raad van mening dat Hertzog eerder moes bedank. Teen hierdie agtergrond, en in die atmosfeer van vyandelikheid wat die Ellis-kamp teen hom uitgestraal het, het Hertzog gevolglik in September 1950 sy bedankingsbrief aan Ellis oorhandig wat deur die MWU-uitvoerende bestuur aanvaar is. ${ }^{37}$ Hertzog was egter steeds 'n erelid van die MWU en sou in daardie hoedanigheid voorlopig nog amptelik by die vakbond betrokke bly. ${ }^{38}$

Te midde van die voortgesette twis tussen Ellis en die "Groot Drie", soos hy na Hertzog, Paul Visser en Jan Gleisner verwys het, ${ }^{39}$ is die verslag van die Hoek-kommissie van Ondersoek uiteindelik teen die einde van November 1950 aan die MWU oorhandig. Daarvolgens was die oorspronklike

35 (TAB) A 1731 SJ Botha-Versameling, Vol.7, Lêer III: Getuienis, J Gleisner - P Hoek, 29.8.1950, pp.1-2.

36 Ibid., Vol.7, Lêer I: Getuienis, Gleisner-pamflet; (INEG) PV 451, JAM Hertzog-Versameling, Lêer nr. 4/1/180: Dagboek, September 1950, pp.3042,3055,3069, Desember 1950, pp. 3202-3203; Ibid., Lêer nr. 1/266/7/29: J Gleisner, Accusation against DE Ellis, 29.8.1950, p. 4.

37 (INEG) PV 451, JAM Hertzog-Versameling, Lêer nr. 4/ 1/ 180: Dagboek, September 1950, pp. 3060, 3066, 3070-3078, 3081, Oktober 1950, p. 3107, Desember 1950, p.3202; Ibid., Lêer nr. 4/1/183: Dagboek, Oktober 1951, p. 4073; MWU-Argief, Notule van die Maandelikse Vergadering van die Uitvoerende Bestuur, 26.9.1950, p. 5; Patterson: The Last Trek, p. 157; "Hertzog Uit Mynbondbestuur" (Dagbreek en Sondagnuus, 1.10.1950).

38 Patterson: The Last Trek, p. 157.

39 "Bly Kalm" (Die Mynwerker, 13.4.1951, p. 3). 
eienaars van die Transafrika-gebou, dr. en mev. HG Luttig, selfs bereid om die gebou teen $£ 140000$ te verkoop, maar dit is uiteindelik deur die inisiatief van Ellis vir $£ 176000$ aan die MWU verkoop. Kritzinger het as verkoopsagent 'n wins van $£ 23000$ uit die transaksie gemaak. Ellis, wat klaarblyklik van Kritzinger se opsie om die Transafrika-gebou vir die Luttigs te verkoop, bewus was, asook die feit dat laasgenoemde die eintlike eienaars van die gebou was, het geen poging aangewend om dit teen 'n laer prys aan te koop nie, en het geen onafhanklike geswore waardasie laat doen om vas te stel of die koopprys 'n redelike prys in vergelyking met soortgelyke eiendomme in die omgewing was nie. Die kommissie was van mening dat daar tekens van gebrek aan 'n gesonde finansiële beleid in die MWU te bespeur was "wat moontlik tot geldelike wanbestuur gelei het of mag lei", maar kon nie tot 'n duidelike gevolgtrekking kom dat korrupsie bo alle twyfel gepleeg is nie. Gevolglik het die Hoek-kommissie van Ondersoek aanbeveel dat die MWU-uitvoerende bestuur of die algemene raad dit sterk oorweeg om die Minister van Arbeid te versoek om 'n geregtelike kommissie van ondersoek na die Transafrika-aankoop aan te stel. ${ }^{40}$

\section{Die Geregtelike Kommissie van Ondersoek, 1951}

Waar Albert Hertzog nog gehoop het dat Gleisner se pamflet aangaande die Transafrika-korrupsie-aantygings en die status van die Hoekkommissie weens laasgenoemde se ontoeganklikheid vir die media nie 'n groot trefwydte sou hê nie en derhalwe nie te veel skade aan die reputasie van die MWU sou aanrig nie,,$^{41}$ is sy grootste vrese egter bewaarheid toe die bom in Maart 1951 in die openbaar gebars het. George Sutter, die VP-LV vir Springs, het die Gleisner-pamflet, waarvan 2000 eksemplare op die Witwatersrand versprei is, in die parlement onthul en verklaar dat Ellis nieteenstaande Gleisner se krasse aantygings geen geregtelike stappe teen laasgenoemde vir laster gedoen het nie. Gevolglik het hy die regering versoek om 'n kommissie van ondersoek na die hele Transafrikaaangeleentheid in te stel. Sutter het ook vir Hertzog daarvan beskuldig dat hy met die aanstelling van die nie-amptelike Hoek-kommissie van Ondersoek die kwessie probeer toesmeer het. ${ }^{42}$

40 Sien (UG) 52 - 1951 Unie van Suid-Afrika: Verslag van Ondersoek insake die Mynwerkersunie, pp. 3-7; (TAB) A 1731 SJ Botha-Versameling, Vol.7, Lêer I: Verslag van die Kommissie van Ondersoek aangestel deur die Mynwerkersunie by 'n Spesiale Vergadering op 22 Julie 1950 om Ondersoek te doen aangaande die Aankoop van Transafrika-gebou, pp. 4-52.

41 (INEG) PV 451, JAM Hertzog-Versameling, Lêer nr. 4/ 1/ 180: Dagboek, September 1950, pp. 3054, 3070.

42 Ernst Stals (red.): Afrikaners in die Goudstad. Deel II 1924-1961. Pretoria: HAUM, 1986, p. 78; "Geen Bewyse van Onwettige Optrede" (Die Transvaler, 13.3.1951); "Gleisnerpamflet in Volksraad te Berde" (Die Vaderland, 13.3.1951); "Rand M.P. Alleges Mine Union Scandal" (Rand Daily Mail, 13.3.1951); "More about Affairs of Miners' Union" (The Cape Times, 13.3.1951). 
Hertzog, wat heimlik met Sutter saamgestem het in die sin dat hy ook van mening was dat Ellis aan korrupsie skuldig was en dat daar teen hom opgetree behoort te word, het homself in die onbenydenswaardige posisie bevind om Ellis en die MWU-uitvoerende bestuur in die parlement te verdedig ten einde sy eie reputasie, sowel as dié van die NP en die Hoekkommissie, te beskerm. Hertzog het die Hoek-kommissie verdedig deur te verklaar dat sou 'n lastersaak teen Gleisner ingestel word dit slegs 'n aanvalsplatform aan die Johannesburgse Engelstalige pers sou bied om "gif" teen die mynwerkers en die Afrikaners te versprei. ${ }^{43}$

Sake het uiteindelik 'n wending geneem toe die Verre-Oos-Randse distrikskomitee van die MWU, wat 2500 mynwerkers verteenwoordig het en waar Paul Visser se sterkste steunbasis gesetel was, die Minister van Arbeid versoek het om 'n geregtelike kommissie van ondersoek met 'n regter as lid na die Transafrika-aankoop in te stel - dit nadat Visser sodanige ondersoek tydens die maandelikse vergadering van die MWU-uitvoerende bestuur in Maart 1951 voorgestel het, maar dit met 'n oorgrote meerderheid van stemme verslaan is. Gevolglik het Ben Schoeman, die Minister van Arbeid, in April 1951 'n Geregtelike Kommissie van Ondersoek na die MWU-eiendomstransaksie in die parlement aangekondig. 'n Driemankommissie sou onder voorsitterskap van regter Quartus de Wet fungeer. ${ }^{44}$ Dit blyk dat ook in hierdie geval daar sovêr moontlik gepoog is om skadebeheer vir die NP-regering en die Nasionaalgesinde MWU toe te pas. Volgens Hertzog sou Schoeman glo aan hom gesê het dat regter De Wet die enigste Nasionalis was wat vir die kommissie beskikbaar was en dat hy nie iemand op die kommissie van ondersoek wou aanstel "wat op 'n ketterjag sal uitgaan nie". ${ }^{45}$

Met die versoek aan die regering vanuit MWU-geledere self om 'n geregtelike kommissie van ondersoek na die Transafrika-aangeleentheid in te stel, is die handskoen finaal die Ellis-kamp toegewerp. Ellis en sy ondersteuners op die uitvoerende bestuur, het na hierdie versoek, soos dit ook tydens die Hoek-kommissie van Ondersoek die geval met Hertzog, Gleisner en Paul Visser was, die posisie van laasgenoemde, as MWU-president en enigste oorblywende "Ellis-teenstander" van die oorspronklike drietal, deur middel van mosies van wantroue absoluut onhoudbaar begin

43 (INEG) PV 451, JAM Hertzog-Versameling, Lêer nr. 4/1/180: Dagboek, September 1950, p.3042; "Government Accused of being afraid to Ventilate Case" (Rand Daily Mail, 15.3.1951); "Hertzog daag Sutter uit oor Gleisner-Pamflet" (Die Vaderland, 15.3.1951).

44 (SAB), Archives of the Treasury, Vol. 5740, file no. 33/611, Commissions \& Committees: Commission of Enquiry (1951) Mine Workers' Union, Secretary for Labour - Secretary to the Treasury, 17.4.1951; MWU-Argief, Notule van die Maandelikse Uitvoerende Bestuursvergadering, 27.3.1951, p. 3; Stals: Afrikaners in die Goudstad. Deel II, p.78; Walker and Weinbren: 2000 Casualties, p. 223; "Regering gelas 'n Ondersoek" (Die Transvaler, 6.4.1951); "Schoeman Appoints Judicial Inquiry" (Die Mynwerker, 6.4.1951, p.1).

45 (INEG) PV 451, JAM Hertzog-Versameling, Lêer nr. 4/1/182: Dagboek, April 1951, p. 3696. 
maak. ${ }^{46}$ Visser is uiteindelik tydens die driejaarlikse verkiesing van lede vir die algemene raad in November 1951 as MWU-president uitgewerk toe Rassie Erasmus as enigste nominasie tot die amp verkies is. ${ }^{47}$

Wat die aankoopproses van die Transafrika-gebou betref, het die De Wetkommissie in wese tot dieselfde bevindinge as die Hoek-kommissie van Ondersoek gekom en gewag gemaak van die buitensporige aankoopprys vir die gebou, asook van die groot kommissie wat Kritzinger vir sý aandeel aan die kooptransaksie verdien het. 'n Ernstige aspek wat die bevindinge van die De Wet-kommissie in 'n ietwat ander lig as dié van die Hoek-kommissie geplaas het, was getuienis aangaande sogenaamde "vergoeding" wat Ellis van Kritzinger sou verkry. Daarvolgens is Ellis 'n derde aandeel aan 'n drankwinkel in Johannesburg aangebied. En tog het die De Wet-kommissie van ondersoek aangaande die korrupsieaantygings teen Ellis tot dieselfde onbesliste gevolgtrekking as dié van die Hoek-kommissie gekom deur te verklaar dat hulle nie van plan was om aanbevelings in daardie verband te doen nie. ${ }^{48}$

Na die verskyning van die De Wet-kommissie se verslag was Albert Hertzog meer as ooit daarvan oortuig dat Daan Ellis skuldig aan die "smet" van korrupsie was. As gevolg sy korrupsie het die kommuniste toe glo oral die leiers van die Afrikanerwerkers "beklad". Volgens Hertzog het die feit dat Ellis hom volgens eie erkenning met "klakkelose napraters" en "stommerike" soos Rassie Erasmus, en met organiseerders "van 'n uiters swak kaliber" as sy "handlangers en inkruipers" omring het, veroorsaak dat hy al hoe meer diktatoriaal begin optree het sonder dat enigeen op die bestuur sy "korrupte" optrede aan bande kon lê. Ellis het dus 'n "tweede Brodrick" geword wat die uitvoerende bestuur geïntimideer het en daarom moes daar van hom ontslae geraak word. Soos ander Ellisteenstanders het Hertzog gevoel dat die Minister van Arbeid moes ingryp om die "pynlike situasie" in die MWU op te los. ${ }^{49}$

Hertzog wou verder gaan om deur middel van die NRT te poog om Ellis as hoofsekretaris "verwyder" te kry. Volgens sy dagboekinskrywings was daar selfs sprake dat vooraanstaande Pretoriase lede van die AB, soos Victor Hiemstra, Dirk Hertzog, PW Hoek, Schalk Botha en Gert Beetge,

46 Sien bv. MWU-Argief, Notules van die Maandelikse Uitvoerende Bestuursvergadering, 27.3.1951 tot 29.10.1951; (INEG) PV 451, JAM Hertzog-Versameling, Lêer nr. 4/1/182: Dagboek, Maart 1951, pp.3676,3679-3680,3685, April 1951, pp. 3711-3712, Julie 1951, p. 3819; Stals: Afrikaners in die Goudstad. Deel II, p. 78.

47 MWU-Argief, Notule van die Algemene Raadsvergadering, 21.11.1951, p.1; "New Executive Elected" (Die Mynwerker, 23.11.1951, p. 1).

48 (UG) 52 - 1951 Unie van Suid-Afrika: Verslag van die Kommissie van Ondersoek insake die Mynwerkersunie, pp. 3-11.

49 (INEG) PV 451, JAM Hertzog-Versameling, Lêer nr. 4/1/179: Dagboek, Mei 1950, p. 2797; Ibid., Lêer nr. 4/ 1/180: Dagboek, Augustus 1950, p. 3025, Oktober 1950, p.3104; Ibid., Lêer nr. 4/ 1/183: Dagboek, Oktober 1951, pp. 4083-4086, 4097; "Minister should now intervene, suggests Dr. Albert Hertzog" (Rand Daily Mail, 9.10.1951).

TD, 2 (1), July 2006, pp. 145-164 
as 'n deputasie na die organisasie se Uitvoerende Raad sou gaan om hulle te versoek "om stappe te neem" om Ellis as MWU-hoofsekretaris te "verwyder". Ellis sou eers deur die AB oorreed kon word om te bedank en as hy sou weier, sou die Minister van Arbeid versoek word om wetgewing in te dien wat persone met korrupsie-aanklagte teen hulle sou belet om in vakbondbesture te dien. Die plan het egter deur die mat geval toe die genoemde persone kop uitgetrek het. Dit wil voorkom of die AB geensins daarmee gelukkig was dat 'n "stryd tussen sekere medelede" (Hertzog en Ellis) gewoed het nie. Volgens Avril Malan, 'n AB-lid, kon die twis binne die MWU 'n "swaar verlies" vir die NP in die volgende verkiesing beteken. Daarom moes Hertzog hom aan die stryd teen Ellis onttrek, selfs al sou hy "miskien korrup" wees.

Hertzog het klaarblyklik uiters teensinnig daartoe ingestem op voorwaarde dat Ellis ook aanvalle op hom sou staak. Vir Hertzog was dit 'n bitter pil om te sluk aangesien sy "vroeëre (vriende)" van hom vereis het dat sy "lewenstaak", om die blanke werkers van Suid-Afrika agter die NP en die Afrikanervolk te kry, so "vernietig" moes word. Dit het waarskynlik ook daartoe bygedra dat hy al hoe meer ontnugter met die AB geraak het aangesien politieke inmenging die organisasie volgens hom "stadigaan al hoe lammer gemaak" het sodat 'n "gees van verval daaroor gehang het". ${ }^{50}$

4. 'n Ontleding van die redes vir Hertzog se betrokkenheid by die twis in MWU-geledere

As politikus is dr. Albert Hertzog se betrokkenheid by die twis in MWUgeledere tydens die Ellis-bewind sekerlik die prominentste. Verskeie bronne maak melding van Hertzog se groot ambisie om na die NP se bewindsoorname in 1948 as Minister van Arbeid aangestel te word. ${ }^{51}$ Hierdie siening moet egter genuanseerd teen die agtergrond van sy filosofie en strategie vir die verowering van blanke vakbonde vir die Afrikanersaak vertolk word. Ten eerste is Ben Schoeman deur dr. Malan met 'n ministerskap beloon omdat hy instrumenteel daartoe was om die Afrikanerparty van Klasie Havenga in 'n koalisie aan die NP te verbind wat die verkiesingsoorwinning in 1948 verseker het. Daarby was Schoeman, in teenstelling met Hertzog, in daardie stadium alreeds 'n senior lid van die party. Albert Hertzog was ook nie 'n politieke "spanspeler" ten opsigte van partypolitieke gedienstigheid nie, aangesien hy en enkele

50 (INEG) PV 451, JAM Hertzog-Versameling, Lêer nr. 4/1/183: Dagboek, November 1951, pp.4117-4119, Desember 1951, pp. 4173-4176, 4196; Ibid., 4/1/184: Dagboek, Maart 1952, pp. 4371-4372, 4376, 4409-4410, September 1952, pp. 4596-4597.

51 Sien bv. Ferdinand Postma-Biblioteek, Noordwes-Universiteit, Ossewa BrandwagArgief, Band nrs. 81-82: Herinneringe van Mnr. GM van der Walt (17 Januarie 1975); Ben Schoeman: My Lewe in die Politiek. Johannesburg: Perskor-Uitgewery, 1978, pp. 149-150, 341; Beaumont Schoeman: Die Broederbond in die Afrikaner-Politiek. Pretoria: Aktuele Publikasies, 1982, pp. 32-33. 
vriende 'n soort onafhanklike indiwidualisme en afsydigheid binne die NP gehandhaaf en dikwels kritiek jeens partybeleid uitgespreek het. Volgens Beamont Schoeman het indiwidue in die NP soos Hertzog aanvanklik meer toegeneentheid teenoor die Afrikanerparty, die Nuwe Orde en die Ossewa Brandwag geopenbaar.

Omdat Hertzog invloed op kulturele en politieke terrein deur middel van indiwidue, klein selgroeperings en frontorganisasies buiteom partyverband probeer bewerkstellig het, is hy deur sommige NP-politici gewantrou en van die breë koukus in die party geïsoleer. Hy is met agterdog bejeën as sou hy 'n persoonlike magsposisie in vakbonde soos die MWU ten koste van sy politieke kollegas wou opbou en is daarom as 'n "gevaar" vir die party beskou. NP-leiers soos Strijdom, Verwoerd en Vorster het glad nie van Hertzog gehou nie en van sý kant af was die gevoel wedersyds. Dit is waarskynlik ook teen hierdie agtergrond dat sommige persone in die AB gevoel het dat Hertzog sy stryd om Ellis uit die MWU te verwyder moes laat vaar. Dit sou glo daartoe lei dat hy te veel invloed in die vakbond verkry wat weer 'n te sterk "drukgroep" teen die NP sou kon vorm.

Volgens Hertzog, wat onthutsend eerlik in sy dagboekinskrywings blyk te wees, wou hy Minister van Arbeid word, nie om sy ambisie te bevredig nie, maar om die ideaal van die verowering van die blanke vakbonde te laat seëvier om sodoende die lojaliteit van die Afrikanerwerker vir die NP en die Afrikanersaak te verseker. Hertzog was van mening dat die bereiking van hierdie ideaal ten beste vanuit 'n ministeriële magsposisie bewerkstellig kon word en weens sy jarelange betrokkenheid by die stryd om die verowering van die MWU het hy geglo dat hý die Afrikanerpolitikus was wat deur sy ondervinding die beste daartoe in staat was. So gesien, sou die vergelyking gemaak kon word dat Hertzog, soos 'n feodale leenheer van ouds, die MWU as sy persoonlike (politieke) "leengoed" beskou het. Sy eiesoortige siening van die verowering van die vakbonde het beslis nie in alle opsigte met die NP se beleidsriglyne en 'n gedurig veranderende politieke dinamika ooreengestem nie. Die wantroue van sy kollegas, sowel as sy afsydigheid en politieke eiegeregtigheid ten opsigte van partybeleid, het 'n groot bydrae gelewer tot Hertzog se uiteindelike afdanking uit die kabinet deur Premier John Vorster in 1968 en die totstandkoming van sy Herstigte Nasionale Party (HNP) in 1969. ${ }^{52}$

52 Sien (INEG) PV 451, JAM Hertzog-Versameling, Lêer nr. 4/1/180: Dagboek, September 1950, pp.3061-3065; Ibid., Lêer nr. 4/ 1/182: Dagboek, Junie 1951, pp.3792-3793,3802; Ibid., Lêer nr. 4/ 1 / 184: Dagboek, Januarie-Desember 1952, pp. 4369-4370, 4372-4373; Dan O'Meara: Forty Lost Years. The Apartheid State and the Politics of the National Party, 1948-1994. Randburg: Ravan Press, 1996, pp. 118-119, 165; Schoeman: My Lewe in die Politiek, pp. 134-136, 334-335, 341-342, 364-367; Schoeman: Die Broederbond in die Afrikaner-Politiek, pp. 11, 17-33; Privaatonderhoud met mnr. SP Botha, 27.5.2002. 


\section{Gevolgtrekking}

Dat Albert Hertzog 'n omstrede figuur in die Suid-Afrikaanse politiek gedurende die apartheidsera was, lei geen twyfel nie. Enersyds kan die moontlikheid dat hy 'n persoonlike politieke ambisie en later 'n eie politieke agenda ten opsigte van sy betrokkenheid by en bemoeienis met die Afrikanerwerker in die geheel en die MWU in die besonder gekoester het, nie buite rekening gelaat word nie. Andersins het Hertzog, as die eerste Nasionaalgesinde Afrikaner politieke leier wat hom daadwerklik en ten nouste met die sosio-politieke lotgevalle van die Afrikanerwerkersklas bemoei het, homself ook die posisie van 'n politieke vaderfiguur oor hulle toegeëien. Soos reeds genoem, was Hertzog daarvan oortuig dat, van al die Afrikaner politieke leiers, hý oor die meeste kennis en ervaring beskik het om die belange van hierdie komponent van die Afrikanerdom te beskerm en hulle politieke lojaliteit vir die NP van 'n DF Malan, 'n JG Strijdom en 'n HF Verwoerd te konsolideer. Dit is opvallend dat daar klaarblyklik nog geen deurtastende biografiese studie oor dr. Albert Hertzog en sy politieke motiewe gedoen is nie.

Oor die redes daarvoor kan net bespiegel word. Voorheen beperkte toegang tot die JAM Hertzog-versameling, waarvoor goedkeuring verkry moes word, sou moontlik 'n faktor kon wees. Die demoniseringsrol wat Nasionaalgesinde koerante uit die Naspersstal gedurende die felle verligteverkrampte-stryd van die jare sestig en sewentig gespeel het om Hertzog tot paria-figuur in Afrikaner politieke geledere verklaar te kry, moet egter ook nie uit die oog verloor word nie.

Vrae wat ten opsigte van daardie aspek van die Suid-Afrikaanse geskiedenis nog onbeantwoord is, is byvoorbeeld die volgende: In watter mate en hoekom het Hertzog se siening verskil van dié van die NP ten opsigte van die politieke koers wat aangaande Afrikanernasionalisme, die Afrikaners en hulle republiek ingeslaan moes word? En was die wegbreek van die Hertzog-groepering uit die NP in 1969 inderdaad die afgooi van 'n konserwatiewe meulsteen om die nek van laasgenoemde waardeur die weg vir hervormingsgesindes in die party gebaan is om uiteindelik ook met apartheid teen die einde van die twintigste eeu te breek? 'n Wetenskaplike historiese studie, wat ook grondige navorsing in die Hertzog-versameling by INEG behels, sal groter lig kan werp op hierdie vrae en op Hertzog self as politieke persoonlikheid in die Suid-Afrikaanse geskiedenis. 